\title{
Relationship between stunting with dental and oral status in toddlers
}

\author{
Munifah Abdat, ${ }^{1 *}$ Said Usman, ${ }^{2}$ Chairunas,${ }^{3}$ Hafidha Suhaila ${ }^{4}$
}

\section{Abstract}

Objective: To find out the relation between stunting and the dental and oral status of toddlers.

Materials and Methods: An analytic observational study with a cross-sectional approach in Pidie district, Aceh. The subject consists of 70 stunting and normal toddlers. The method used is by measure the deft index and OHIS (Oral Hygiene Index Simplified) in toddlers, and also giving questionnaires patterns of dental and oral health behavior. Processing of research data using SPSS 24.0 with Pearson Correlation test and Kendall tau test, also significant value $p<0.05$.

Results: Based on questionnaire results, many parents of stunted no attention to his oral hygiene of their toddlers. The results of measurements with deft index in stunting and normal toddlers show stunting toddlers at 6.13 (very high category) and normal toddlers 3.7 (Moderate category). Analytic with Pearson correlation test between nutritional status (stunting and normal) and deft results were $0.023<0.05$ and OHIS were $0.010<0.05$. Kendall's tau test results showed a value of $0.020<0.05$. There is a relationship between nutritional status variables with deft and there is a relationship between nutritional status variables and 0 HIS.

Conclusion: There was a significant relationship between stunting with the dental and oral status in toddlers, the strength of the correlation is sufficient.
'Department of Dental Public Health, Faculty of Dentistry, Syiah Kuala University, Banda Aceh, Indonesia

${ }^{2}$ Department of Public Health, Faculty of Medicine, Syiah Kuala University, Banda Aceh, Indonesia ${ }^{3}$ Department of Oral Maxillofacial Surgery, Faculty of Dentistry, Syiah Kuala University, Banda Aceh, Indonesia

${ }^{4}$ Faculty of Dentistry, Syiah Kuala University, Banda Aceh, Indonesia

*Correspondence to: Munifah Abdat, Department of Dental Public Health, Faculty of Dentistry, Syiah Kuala University, Banda Aceh, Indonesia munifahabdat_dr@unsyiah.ac.id

Received: 8 June 2020 Revised: 26 June 2020 Accepted: 19 July 2020 Available Online: 1 August 2020
Keywords: Dental and oral status, Stunting, Toddler

Cite this Article: Abdat, M., Usman, S., Chairunas, Suhaila, H. 2020. Relationship between stunting with dental and oral status in toddlers. Journal of Dentomaxillofacial Science 5(2): 114-119. D0l: 10.15562/jdmfs.v5i2.1064

\section{Introduction}

Stunting is a state of the short body based on age to deficit <-2 Standard Deviation (SD) below the median standard length or height according to age. ${ }^{1}$ Assessment Standards use height indicators for age (TB / U) according to the World Health Organization (WHO), a child growth standard that is an assessment of the $\mathrm{z}$-score of TB / U <-2 SD. ${ }^{2}$

Stunting disorders can start from the process of growth and development of the fetus in the womb until the age of 2 years. Stunting is measured using indicators of height measurement for age (TB / $\mathrm{U})$ according to WHO, child growth standard is when the $\mathrm{Z}$-score TB / $\mathrm{U}<-2 \mathrm{SD} .{ }^{3}$ Since the first day of pregnancy, the birth of a baby for up to 2 years is the first 1000 days of human life called the windows opportunity. ${ }^{4}$ The calculation criteria for Non stunting are z-score 0-1 SD, mild stunting $\mathrm{z}$-score $<-2 \mathrm{SD}$ and severe stunting $\mathrm{z}$-score $<-3 \mathrm{SD} .^{5}$

One of the etiologies of stunting is a deficiency or reduced nutritional intake for a long time, resulting in disruption of growth and causing growth retardation. ${ }^{6}$ Child malnutrition is a common cause of disability and death among children under 5 years in developing countries and can cause several disorders, including disorders related to diet and the frequency of caries. ${ }^{7}$ The percentage of stunting at 3-5 years of age becomes normal at 7-9 years of age is $84.3 \%$. $83-5$ years is the age for children in the toddler age category. ${ }^{8,9}$

UNICEF / WHO / World Bank Group Joint Child Malnutrition Estimates report that there are 79 billion stunting children under 5 years in the Asia Pacific region. In 2000 and 2006 there were reductions in some regions such as the South Korea region reaching 30\% and East Asia reaching 71\%, but there was no reduction in the Southeast Asian region. ${ }^{10}$

Indonesia is one of the countries with the highest prevalence of stunting in the world, with a prevalence of up to $30.8 \%$ based on WHO health agency reports. ${ }^{11}$ Aceh is a province with the 3rd highest prevalence of stunting for toddlers in Indonesia. ${ }^{12}$ Based on a survey of monitoring the nutritional status of Aceh province in 2017 the regency or city in Aceh which has the highest number for stunting status is Pidie $29.1 \%$ and sub-natural in $21.3 \%$ while for Banda Aceh has $17.7 \%$ of stunting events. ${ }^{13}$

The development of salivary glands in patients with stunting can also experience atrophy, causing reduced salivary secretion. ${ }^{14}$ Decreased salivary flow can be caused by a lack of masticatory activity that can occur in children who lack food intake. ${ }^{15}$ Stunting can result in disruption of tooth maturation, impaired enamel development, and delayed eruption of deciduous teeth. ${ }^{7}$ Dental caries is a 
chronic disease that often occurs in childhood, which is $60-90 \%$ of cases. Dental caries must be treated to prevent chronic mouth infections and oral pain. ${ }^{7}$ The high frequency of caries can be caused by malnutrition, and lack of knowledge of oral health. ${ }^{16}$

Epidemiological research shows that a causal link between malnutrition and caries can also cause morbidity. Preventing and treating early childhood caries will improve oral health so that it provides benefits for children in the short and long term.'

\section{Material and Methods}

This research was conducted in August-September 2019 in Mutiara Timur sub-district, Simpang Tiga, Kembang Tanjung, Tiro, and Tangse in Pidie district. This type of research is an analytic observational study with a cross-sectional approach. The sample consisted of 70 stunting and normal toddlers.

\section{Table 1 General Characteristics of the Subject study from Mother's} Toddlers

\begin{tabular}{|c|c|c|c|c|}
\hline \multirow[b]{2}{*}{ Variable } & \multicolumn{2}{|c|}{ Stunting } & \multicolumn{2}{|c|}{ Normal } \\
\hline & $\mathbf{N}$ & $\%$ & $\mathbf{N}$ & $\%$ \\
\hline \multicolumn{5}{|l|}{ Age } \\
\hline 3 years & 16 & 44.44 & 21 & 65.62 \\
\hline 4 years & 20 & 55.56 & 12 & 35.29 \\
\hline 5 years & 0 & 0 & 1 & 2.94 \\
\hline Total & 36 & 100 & 34 & \\
\hline \multicolumn{5}{|l|}{ Level of education } \\
\hline Basic School & 3 & 8.33 & 0 & 0 \\
\hline Junior High School & 8 & 22.22 & 9 & 26.47 \\
\hline Senior High School & 19 & 52.77 & 18 & 52.94 \\
\hline Diploma & 1 & 2.77 & 2 & 5.88 \\
\hline Bachelor & 5 & 13.88 & 5 & 14.7 \\
\hline \multicolumn{5}{|l|}{ Profession } \\
\hline housewife & 32 & 88.88 & 22 & 64.7 \\
\hline Furnishers & 0 & 0 & 1 & 2.94 \\
\hline Farmers & 3 & 8.33 & 4 & 11.76 \\
\hline Government employees & 1 & 2.77 & 2 & 5.88 \\
\hline Honorary & 0 & 0 & 2 & 5.88 \\
\hline Midwife & 0 & 0 & 1 & 2.94 \\
\hline Trader & 0 & 0 & 1 & 2.94 \\
\hline \multicolumn{5}{|c|}{ Family Income Level (in Rupiah) } \\
\hline$<1.500 .000$ & 29 & 80.55 & 25 & 73.52 \\
\hline $1.500 .000-2.500 .000$ & 5 & 13.88 & 8 & 23.52 \\
\hline $2.500 .000-3.500 .000$ & 2 & 5.55 & 0 & 0 \\
\hline$>3.500 .000$ & 0 & 0 & 1 & 2.94 \\
\hline
\end{tabular}

Subjects were determined by looking at the inclusion criteria, namely stunting toddlers and normal toddlers aged 3-5 years, and is willing to be the subject of research with an informed consent letter. Subject selection was carried out using a questionnaire filled out by the subject.

Researchers perform oral hygiene checks. The study was conducted for 10 minutes for interviews and filling out the research examination forms and 10 minutes for an oral examination. Within a day will be examined on 10 children in seven days. During the examination researchers used self-protection devices (universal coverage). Research subjects sitting and facing a lighting source (can be assisted with a flashlight) can also be examined by the child with the head position on a pillow close to the position of the researcher making it easier to see the child's entire mouth.

The instrument used for the study was sterilized using an autoclave before the inspection. Examination of the oral hygiene status of the subjects using a mouth glass was then assessed according to the criteria on the specified tooth surface and filled in the OHIS examination sheet. Debris score measurement by determining the score of soft deposits that occur due to food scraps attached to certain teeth. Calculus score measurement is done by placing the periodontal probe in the subgingival area first, then moving from distal to mesial and ascending to the incisal and given a score according to the criteria.

\section{Results}

Subjects in this study were toddlers aged 3-5 years in Pidie district totaling 70 toddlers with 36 stunting children and 34 toddlers who did not experience stunting. This research was conducted by examining de-t, OHIS, and filling forms of dental health behavior patterns.

Based on table 1, it shows that the education level of stunting mother children in the district of pidie is at the level of high school as much as $52.77 \%$ (19 people) and normal child mothers are $52.94 \%$ (18 people). For the most work level for mothers of stunting children are housewives at $88.88 \%$ (32 people) and in mothers of normal children $64.7 \%$ (22 people). The highest level of family income of stunting children is $1,500,000$ as much as $80.55 \%$ (29 people) and in normal children's families $73.52 \%$ ( 25 people). The gender criteria there are 14 stunting boys (38.88\%) and 21 normal boys (61.76\%). The number of stunting female children was $22(61.11 \%)$ and normal girls were $13(38.23 \%)$. There were more female subjects than male subjects in stunting children, and more male subjects in the normal child subject category. 
Table 2 Relationship of deft measurements base on nutritional status

\begin{tabular}{lccccc}
\hline Nutritional status & D & E & f & deft & Category \\
\hline Stunting & 196 & 25 & 0 & 6.13 & Very high \\
Normal & 116 & 11 & 0 & 3.7 & Moderate \\
\hline
\end{tabular}

Table 3 Distribution of deft measurements by age

\begin{tabular}{llccc}
\hline & & \multicolumn{3}{c}{ Age } \\
\cline { 3 - 5 } No & Nutritional status & $\mathbf{3}$ Years & $\mathbf{4}$ Years & $\mathbf{5}$ Years \\
\hline 1 & Stunting & 5.0 (High) & 7.2 (Very High) & N/A \\
2 & Normal & 3.76 (Moderate) & 3.66 (Moderate) & $3+0+0$ \\
\hline
\end{tabular}

Table 4 Mean deft in stunting and normal toddlers

\begin{tabular}{lcc}
\hline$\overline{\boldsymbol{X}}$ & Stunting $(\mathbf{n}=\mathbf{3 6})$ & Normal $(\mathbf{n}=\mathbf{3 4})$ \\
\hline $\mathrm{d}-\mathrm{t}$ & 5.4 & 3.14 \\
$\mathrm{e}-\mathrm{t}$ & 0.69 & 0.34 \\
$\mathrm{f}-\mathrm{t}$ & 0 & 0 \\
\hline
\end{tabular}

Table 5 Relationship of OHIS measurements based on nutritional status

\begin{tabular}{lcccc}
\hline Nutritional status & DI & Cl & OHIS & Category \\
\hline Stunting & 1.4 & 0.75 & 2.15 & Moderate \\
Normal & 0.94 & 0.3 & 1.2 & Good \\
\hline
\end{tabular}

Based on table 2 shows the frequency based on the results of measurements in stunting and normal children based on nutritional status shows def results in stunting children at 6.13 (very high) and in normal children 3.7 (Moderate).

Based on table 3 shows the frequency distribution based on the measurement results of deft in stunting and normal children based on age, stunting children at 3 years old shows a deft index of 5.0 (High), 4 years of age of 7.2 (Very High) and in normal children at the age of 3 years as many as 3.76 (moderate), at the age of 4 years 3.66 (moderate).

Based on table 4 shows the deft index in stunting children is 6.13 with a dt index of 6 et index of 0.7 and $\mathrm{ft}$ index of 0 . While the mean index in normal children is 3.1 with a dt index of 3 et index of 0.3 and $\mathrm{ft}$ index of 0 . Stunting toddlers have an average of five teeth in caries and normal toddlers have an average of three teeth with caries.

Based on table 5 shows the frequency based on the results of OHIS measurements in stunting and normal children based on nutritional status shows the results of the OHIS index in stunting children of 2.1 (moderate) and in normal children 1.2 (good). The results of OHIS measurements in stunting and normal children based on age, stunting children at 3 years old showed OHIS at 2.06 (moderate),
4 years old at 2.2 (moderate) and in normal children at 3 years old as many as 1.4 (moderate), at the age of 4 years 1.16 (good), 5 years old at 0.8 (good).

\section{Discussion}

Pidie District is one of the three districts in Aceh that has the highest number of stunting status with $29.1 \%$ of stunting incidents. ${ }^{5}$ Malnutrition, and lack of knowledge of oral health can cause a high frequency of caries. ${ }^{16}$ Epidemiological research shows a causal link between malnutrition and caries. ${ }^{7}$ The study was conducted in 5 sub-districts in Pidie district, namely in the Mutiara Timur sub-district, Campli Usi village, Usi Mosque, and Balee Ujong Rimba. Simpang Tiga District, Teungoh Mangki and Nien villages. Kembang Tanjung Subdistrict, Ara village. Tiro District, Panah, Peunadok, and Panton Beunot villages. Tangse sub-district, Ule Gunong village. The number of research subjects were 36 stunting children and 34 normal children.

The majority of mothers of stunting toddlers education in the district of Pidie are high school as much as $52.77 \%$ (19 people) and mothers of normal children $52.94 \%$ (18 people). Education has an important function in improving the welfare of life, and can also affect a person's behavior including health care. ${ }^{17}$ Higher levels of parent education have a relationship to good care for children. ${ }^{18}$ Mother's education is significantly related to the incidence of stunting in infants due to the role of caregiving mothers are more dominant. ${ }^{19}$ Mother's education level influences the ease of mother in absorbing and understanding nutritional knowledge so that mothers can distinguish appropriate methods for setting nutritional standards in the family. Education is needed so that parents are more responsive to family nutrition problems but education is not a major factor causing stunting children, higher education does not guarantee that children will be free from stunting. ${ }^{20,21}$

The highest occupational category for mothers majority housewives. Housewives have much time to care for their children, but if they do not have proper knowledge of care and behavior patterns will also influence the child's nutritional status. ${ }^{22}$ Income is one indicator that determines economic status. The highest category of family income of stunting children is $1,500,00080.55 \%$ (29 people) and $73.52 \%$ ( 25 people) in normal children's families. The household welfare index score is significantly related to increased protection of stunting events. ${ }^{23}$ Families with poor socioeconomic conditions will result in firstborn needs such as food, clothing, and housing not being met. The ability of families to buy food is not only influenced by the amount of income but the price of food. Some 
expensive food ingredients tend not to be selected and bought, so in families these types of food are rarely served so that the nutritional needs are still lacking. ${ }^{24}$

This may be due to the fulfillment of food intake needs that are not following the needs of children will cause interference with the nutritional status and health of children. ${ }^{23}$ So if the longer the child is left with the factors causing the risk of stunting will cause a higher frequency of children experiencing disorders in nutritional status. ${ }^{24}$ The number of female stunting children is more than male children, whereas in normal children, the number of males is more than female. Each parenting pattern has cultural definitions, such as how the food is processed and served is influenced by cultural factors and parents' knowledge of nutritious food for children. ${ }^{21}$ This is allegedly due to the pattern of community care that considers males to get enough nutritional intake due to greater nutritional needs than females. The next effect when a girl stunting to become a mother will potentially give birth to a stunting child until she becomes short cross-generation. ${ }^{8}$

The frequency distribution based on the results of the measurement of deft in stunting and normal children based on nutritional status shows the results of the deft index in stunting children at 6.13 (very high) and in normal children 3.7 (moderate). In stunting children have very high deft results due to atrophy of the salivary glands causing salivary buffering and self-cleansing to decrease which can ultimately increase the occurrence of dental caries. ${ }^{3}$ Frequency distribution based on deft measurement results in stunting and normal children based on age shows stunting children at 3 years old shows a deft index score of 5.0 (High), at 4 years of age of 7.2 (very high). In stunting children aged 4 years experienced higher caries than stunting children who were 3 years old suspected because there was an influence of the time factor of caries. Understanding of time is the speed at which dental caries form and the duration and frequency of the substrate attached to the tooth surface. ${ }^{22}$

Mean deft frequency distribution by adding up all cases of decaying teeth (exfoliation), and filling teeth shows the stunting toddlers have an average of five teeth with caries and normal toddlers have an average of three teeth with caries. The development of salivary glands in children who are chronic malnutrition can experience atrophy resulting in reduced salivary secretion, the function of saliva as a buffer, cleanser, anti-solvent, and anti-bacterial is also reduced. ${ }^{3}$ Consumption of nourishing and cariogenic foods with frequent and repeated frequency will cause ph plaque below normal, causing demineralization of enamel until dental caries eventually occurs in the teeth. ${ }^{20}$

The frequency based on OHIS measurements shows the results of the OHIS index in stunting children at 2.1 (moderate) and in normal children 1.2 (good). Stunting children can experience atrophy of the salivary glands, thereby reducing the oral defense of the ability of self-cleansing. This affects the formation of plaque and calculus..$^{24}$ Several other factors that also affect the formation of debris and calculus are $\mathrm{pH}$, buffering capacity, and calcium. ${ }^{31}$ Based on age, stunting children aged 3 years showed OHIS of 2.06 (moderate), 4 years of age as much as 2.2 (moderate). Dental and oral health in toddlers is affected by malnutrition, disease, maternal knowledge, and social status. ${ }^{18}$ Pathological processes and symptoms in the mouth are often associated with impaired composition and the amount of salivary secretions. The process of secretion in the salivary glands is also influenced by nutrition. A series of studies show that malnutrition during periods of growth and development can disrupt of the permanent salivary gland glands. ${ }^{19}$

The results of the questionnaire questions on dental health behavior patterns associated with the nutritional status of toddlers. Food consumption must be considered, including paying attention to the consumption of foods containing calcium, fiber, glucose and carbohydrates. ${ }^{20} \mathrm{~A}$ balanced diet is needed by the child so that the child gets balanced nutrition. Parents need to pay attention to the selection of healthy foods for children based on a balanced nutritional pyramid, namely milk, consumption of protein found inside dishes, vegetables, fruits, and carbohydrates such as rice, bread, noodles, potatoes, and cereals..$^{21}$ The habits of sweet and sticky foods (chocolate, candy, biscuits) which contain very high sucrose sweeteners increase the acidity in the oral cavity..$^{15}$ Sugary foods like sugar will produce $1 \mathrm{mg} / \mathrm{dl}$ of salivary sugar and can reduce the $\mathrm{pH}$ which results in the demineralization of the teeth. The condition of stunting toddlers who have low saliva causes the power of cleaning (self-cleasing) to below. Pain in teeth and mouth can reduce children's appetite so that children are vulnerable to malnutrition. ${ }^{16}$

The categories of pattern dental health behavior in stunting get bad categories and normal toddlers get enough categories. Consumption of cariogenic foods in large quantities, frequency, and intervals associated with increased dental caries. ${ }^{24}$ Factors Mothers chew first child food to be softer before it is given to children causing the transmission that causes the transfer of bacteria from the mother which is the main resort of Streptococcus mutans. ${ }^{22}$ Society must be know how to maintain proper oral 
and dental hygiene to improve oral health. ${ }^{16}$ It is suspected that many parents of stunted children pay little attention to oral hygiene. The use of toothpaste containing fluoride, fluorine application, filling and cleaning of tartar can be done to reduce the risk of dental caries. ${ }^{19}$ Bad habits in maintaining oral and dental hygiene can cause caries, gingivitis, stomatitis, and also cause damage to the tooth's periondontal tissue. Tooth brushing behavior is related to plaque score, plaque is a factor that causes dental caries and periodontal disease. Remaining food that is not cleaned will cause bacterial metabolism, brushing teeth and dental floss needed to reduce the number of bacterial plaque. ${ }^{13}$

Correlation test the table value of $0.023<0.05$ shows that there is a relationship between the nutritional status of stunting and normal toddlers with dental status (deft). There is a relationship between short nutritional status (stunting) with the level of dental caries in kindergarten students in the Ertak Hanyar sub-district, and causes the function of saliva as a buffer, cleaner, anti-solvent, and anti-bacterial also reduced. ${ }^{3}$ There was also a table value of $0.010<0.05$ shows there is a relationship between the nutritional status of stunting and normal toddlers with oral hygiene (OHIS). Dental and oral health in toddlers is affected by malnutrition, disease, maternal knowledge, and social status. $^{3}$ Pathological processes and symptoms in the mouth are often associated with impaired composition and amount of salivary secretions. ${ }^{23}$ Stunting children who have low saliva conditions cause cleaning power (self-cleansing) is low. ${ }^{24} \mathrm{pH}$, buffering capacity and calcium can also affect the formation of debris and calculus in teeth. ${ }^{20}$

The nutritional status of stunting and normal children with OHIS showed a p-value of 0.020 $<0.05$, then OHIS has a significant relationship to nutritional status. The relationship between nutritional status and OHIS has a sufficient correlation $(0.267)$ and is positive. There is a relationship between nutritional deficiencies with caries and dental and oral hygiene status. If the correlation is positive, the correlation between the two variables is one-sided, meaning that in children with low nutritional status there is a poor oral hygiene condition. ${ }^{21}$

Children who are chronically malnourished (stunting) can experience atrophy, causing reduced salivary secretion. Salivary function is reduced so that it affects the deft index and OHIS. ${ }^{3}$

\section{Conclusion}

The results of measurements with deft index in stunting and normal toddlers show stunting toddlers at 6.13 (very high category) and normal toddlers 3.7 (Moderate category). The results of OHIS measurements in toddlers in the district of Pidie show a moderate category for stunting toddlers and a good category for normal toddlers. There was a significant relationship between stunting with the dental and oral status in toddlers, the strength of the correlation is sufficient.

\section{Acknowledgment}

None.

\section{Conflict of Interest}

The authors report no conflict of interest.

\section{References}

1. Badan Penelitian dan Pengembangan Kesehatan. Riset Kesehatan Dasar RISKESDAS 2013: 21.

2. Rahman T, Rosihan A, Triawatnti. Relationship between stunting and dental caries level. overview of Kindergarten Students in Kertak Hanyar District, Banjar Regency. Dentino J Kedokteran Gigi 2016;1: 88-93 (In Indonesia)

3. Khoeroh $\mathrm{H}$, Indriyanti D. Evaluation of nutritional management for children with stunting in the work area of the sirampog health center. Unnes J Public Health 2015;4: 54-60. (In Indonesia)

4. Sulistianingsih A, Yanti DAM. Lack of food intake as a cause of stunting. J Dunia Kesehatan 2015;5: 71-75. (In Indonesia)

5. Marvin So, Ellenikiotis YA, Hannah MH, et al. Early childhood dental caries, mouth pain, and malnutrition in the Ecuadorian Amazon Region. International Journal of Environ. Res Public Health 2017;14: 1-9.

6. Trihono, Atmarita, Dwi HT, et al. Short (stunting) in Indonesia, problems and solutions. Jakarta: Balai litbang kesehatan; 2015. p. 2-90. (In Indonesia)

7. Kadiresan K, Gough J, Hulshof $\mathrm{K}$, et al. Asia and the pacific regional overview of food security and nutrition. Accelerating Progress Towards the SDGs series of the food and Agriculture Organization of the United Nations 2018: 11-13.

8. Mahadevan K, Velavan S. Analysis of salivary proteins as the biochemical indicators of nutritional status and salivary gland function. Int J Pharm Biol Sci 2013;4: 689-694.

9. Laurence JW. Clinical aspect of salivary biology for the dental clinician. Interv Dental J 2008;1: 7-24.

10. Budiharto. Introduction to health behavioral science and dental health education. Jakarta: Fakultas Kedokteran Gigi Universitas Indonesia; 1998. p. 14-21. (In Indonesia)

11. Supriyanti NT. Relationship between history of breastfeeding, consumption pattern, and incidence of infection and nutritional status of toddlers ages 12-59 months in Baban Village, Gapura District, Sumenep. Airlangga University. J Manajemen Kesehatan Yayasan Rumah Sakit Dr. Soetomo 2014;3: 1-14. (In Indonesia)

12. Muniroh L. The relationship between education level, knowledge level and mother's parenting style with wasting and stunting in poor families. Media Gizi Ind 2015;10: 84-90. (In Indonesia)

13. Septiana R, Djannah RSN, Djamil MD. The relationship between complementary feeding patterns and nutritional status of children aged 6-24 months in the working area of Puskesmas Gedongtengen Yogyakarta. J Kesehatan Masyarakat 2010;4: 2-7. (In Indonesia) 
14. Gewa CA, Yandell N. Undernutrition among kenyan children: contribution of child, maternal, and household factors. Public Health Nutr 2012;15: 1029-1038.

15. Taguri AI, Betilmal SM, Mahmud AM, et al. Risk factors for stunting among under five in Libya. Pub Health Nutr 2009;12: 1141-1149.

16. Lee J, Houser RF, Must A, et al. Disentangling nutritional factors and household characteristics related to child stunting and maternal overweight in Guatemala. Econ Hum Biol 2010;8: 188-196.

17. Syarfaini. Description of nutrition parenting patterns for toddlers in Tapalang District, Mamuju Regency, West Sulawesi Province. J Kesehatan 2014;7: 267-276. (In Indonesia)

18. Liena C, Leyda A, Forner L, et al. Association between the number of early carious lesion and diet in children with a high prevalence of caries. Eur J Pediatr Dent 2015;16: 7-12.

19. Takeuchi K, Furuta M, Takeshita T, et al. Risk factors for reduced salivary flow rate in a Japanese population. the Hisayama study. BioMed Res Int 2015;2015: 1-7.

20. Berkowitz RJ. Causes treatment and prevention of early childhood caries: a microbiologic perspective. J Can Dent Assoc 2003;69: 306 .
21. Johansson I, Lenander LM, Saellström AK. Saliva composition in indian children with chronic proteinenergy malnutrition. J Dent Res 1994;73: 11-19.

22. Kiswaluyo, Dwiatmoko. The state of nutrition and dental caries in children aged 2-5 years in Sumbersari subdistrict, Jember Regency. J Restorasi Endod 1997;3: 14-16. (In Indonesia)

23. Morenike OF. Association between early childhood caries and malnutrition in a sub urban population in Nigeria. Folayan. BMC Pediatr J 2019;19: 1-8.

24. Fajriani, Yusriyanti M. Comparison of efficacy rinsing with cocoa seed extract, green tea catechins extract and lime extract to salivary ph in children suffering ECC (Early Childhood Caries). J Dentomaxillofac Sci 2018;3: 20-23.

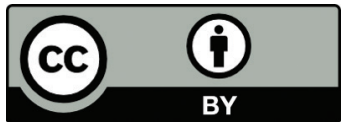

This work is licensed under a Creative Commons Attribution 